\title{
A Novel Carboxy-dye Reactive System of Potential Applicability to Wool and Nylon Fibres. Part 1. Studies with Model Amines
}

\author{
J. I. N. R. Gomes \\ Centro de Tecnologia Têxtil, Universidade do Minho, \\ Palácio Vila Flor, 4800 Guimarães, Portugal \\ J. Griffiths \\ Department of Colour Chemistry and Dyeing, University of Leeds, \\ Leeds, UK \\ H. L. S. Maia, J. C. V. P. Moura \\ \& A. M. F. Oliveira-Campos* \\ Centro de Química Pura e Aplicada (INIC), Universidade do Minho, \\ Av. João XXI, 4700 Braga, Portugal \\ (Received 26 March 1991; accepted 26 April 1991)
}

\section{ABSTRACT}

\begin{abstract}
Dyes containing carboxylic acid groups have the potential to be reacted with the amino groups of wool and nylon fibres by prior activation with ethyl chloroformate (forming a mixed anhydride). The scope of this reaction has been examined in solution using a range of carboxy dyes with cyclohexylamine or lysine as model amine substrates. The expected amides are formed in good yields, and have been isolated and characterised. A preliminary study of the reactive dyeing of wool and nylon-6.6 indicates that dyeings with high wet fastness can be achieved with this system.
\end{abstract}

\section{INTRODUCTION}

Reactive dye systems containing carboxylic acid groups were first developed by Burlington Industries Inc. ${ }^{1}$ in 1978 when it was claimed that they could be

* To whom correspondence should be addressed.

Dyes and Pigments 0143-7208/91/\$03.50 (C) 1991 Elsevier Science Publishers Ltd, England. Printed in Great Britain 
applied to cellulosic fibres successfully at $\mathrm{pH} 4-6$ in the presence of cyanamide, under curing conditions. This reaction was later confirmed and studied for other di-imides. ${ }^{2,3}$

Theoretically these dyes should also react with fibres containing amino groups, such as wool and nylon, with the formation of an amide link. Model experiments ${ }^{4}$ indicate that the cysteine, lysine, histidine, and $\mathrm{N}$-terminal residues of wool are the main sites of reaction with reactive dyes.

Previous workers, investigating the fixation of carboxylic acid dyes on wool using dicyclohexylcarbodi-imide (DCCI) as the activating reagent, found difficulty in obtaining acceptable fixation levels due to competing dyebath hydrolysis. In one case hydrolysis was avoided by the use of organic solvents when applying carboxylic acid dyes in the presencc of DCCI by exhaustion. ${ }^{5}$ In another case the proportion of water mixed with an organic solvent was progressively lowered and padding/thermofixation was used instead of exhaustion. Both procedures resulted in higher fixation yields. ${ }^{6}$ Di-imides other than DCCI were also tested. The methods used in these two cases would however face many practical problems for commercial application to wool, particularly concerning use of solvent, padding efficiency and thermofixation effect on the wool.

We now report an investigation of another activating reagent which might permit the application of carboxylic dyes to wool and nylon by exhaustion from an aqueous dyebath. In order to establish the most suitable dyes and the optimum conditions for producing the amide link, trial condensation reactions were carricd out with model amines representative of the reactive residues of nylon and wool (namely cyclohexylamine and lysine, respectively). The resultant amides were isolated and characterised and the efficiency of the reaction assessed. Preliminary results for the reactions of the dyes with wool and nylon-6.6 fibres are presented.

\section{DISCUSSION}

The carboxy dyes 1a-7a were used in this study. The azo dyes were synthesised by diazotisation of $m$-aminobenzoic acid followed by coupling of the corresponding diazonium salt to the appropriate coupling components ( $\mathrm{H}$ acid, $\mathrm{J}$ acid, $\beta$-naphthol, $N$-phenyl-2-methyl-5-pyrazolone and $N, N$-dimethylaniline). The anthraquinone $3 \mathbf{a}$ was obtained by condensing $m$-aminophenylpropanoic acid with bromaminic acid, in aquenus solution in the presence of $\mathrm{CuSO}_{4}$ and $\mathrm{NaHCO}_{3}$. The blue dye 7a was obtained by condensing $m$-aminobenzoic acid with quinizarin in the presence of zinc and boric acid. 
<smiles>Nc1ccc2c(O)c(N=Nc3cccc(C(=O)O)c3)c(S(=O)(=O)O)cc2c1</smiles>

(1)<smiles>CC(=O)CCc1cccc(Nc2cc(S(N)(=O)=O)c(N)c3c2C(=O)c2ccccc2C3=O)c1</smiles><smiles>[X]C(=O)c1cccc(N=Nc2ccc(N(C)C)cc2)c1</smiles>

(5)<smiles>Nc1cc(S(=O)(=O)O)cc2cc(S(=O)(=O)O[Na])c(N=Nc3cccc(C(=O)O)c3)c(O)c12</smiles>

(2)<smiles>CC(=O)c1cccc(NN=C2C(=O)N(c3ccccc3)N=C2C)c1</smiles>

(b) $\mathrm{X}=-\mathrm{NH} \longrightarrow$

(c) $X=-O E t$<smiles>[R]Oc1ccc2ccccc2c1N=Nc1cccc(C(=O)O)c1</smiles>

(6a) $\mathrm{R}=\mathrm{H}, \mathrm{X}=\mathrm{OH}$

(6b) $\mathrm{R}=\mathrm{COOEt}, \mathrm{X}=-\mathrm{NH}-\mathrm{Ph}$<smiles>O=C(O)c1cccc(Nc2ccc(O[N+](=O)[O-])c3c2C(=O)c2ccccc2C3=O)c1</smiles><smiles></smiles>

(8) 
<smiles>CN(C)c1ccc(N=Nc2cccc(C(=O)NCC(C(=O)[O-])C(=O)[O-])c2)cc1</smiles><smiles>CC1=NN(c2ccccc2)C(=O)/C1=N/Nc1cccc(C(=O)NCC(N)C(=O)[O-])c1</smiles>

The dyes were purified by salting out, crystallisation from dimethylformamide/acetone, or chromatography, and were obtained in yields ranging from 62 to $90 \%$. They all gave acceptable elemental analyses. The carboxylic acid dyes were then reacted with cyclohexylamine and in the case of $\mathbf{4 a}$ and $\mathbf{5 a}$, also with lysine, using an activating agent. These amines were chosen to simulate nylon and wool. The corresponding amides $\mathbf{1 b}-\mathbf{7 b}$ and $\mathbf{8 - 1 0}$ were isolated and identified.

In the first instance dicyclohexylcarbodi-imide was used as the activating reagent for the carboxylic group prior to reaction with the amine. It was found that it was very difficult to obtain pure amides due to contamination of the products with dicyclohexylurea. A mixed anhydride method was then examined, using ethyl chloroformate as the activating reagent. ${ }^{7}$ The dye was dissolved in dimethylformamide (DMF) and was reacted with ethyl chloroformate and triethylamine at low temperature $\left(-5\right.$ to $\left.-10^{\circ} \mathrm{C}\right)$ to form the mixed anhydride (Scheme 1). The amine was then added and the reaction continued at room temperature. In this case, the by-products from the reaction did not cause problems in the isolation of the resultant amides. (The liberated $\mathrm{HCl}$ is neutralised with triethylamine and the other products are $\mathrm{CO}_{2}$ and ethanol.) The amides $\mathbf{1} \mathbf{b}-\mathbf{7} \mathbf{b}$ and $\mathbf{8}$ were obtained in yields ranging from $31 \%$ to $100 \%$ (Table 1) and were characterised after

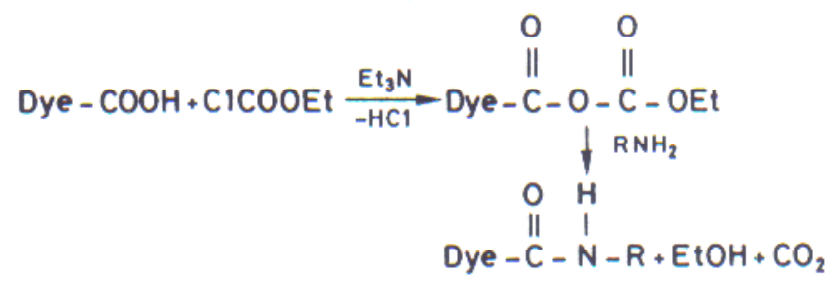

Scheme 1 
TABLE 1

Reaction of Carboxy Dyes with Cyclohexylamine using Ethyl Chloroformate as Activating Agent

\begin{tabular}{|c|c|c|c|}
\hline Product & $\begin{array}{l}\text { Number of } \\
\text { equivalents of } \\
\mathrm{ClCO}_{2} \mathrm{Et}\end{array}$ & $\begin{array}{l}\text { Yield } \\
(\%)\end{array}$ & Method of purification \\
\hline $\mathbf{1 b}$ & $3 \cdot 5$ & 50 & $\begin{array}{l}\text { Preparative plate, silica. Solvent: } n \text {-butanol, } \\
n \text {-propanol, ethyl acetate, water }(2: 4: 1: 3) \text {. }\end{array}$ \\
\hline $2 \mathbf{b}$ & $3 \cdot 5$ & 50 & P. plate, cellulose, same solvent. \\
\hline $3 \mathbf{b}$ & $2 \cdot 0$ & 100 & P. plate, cellulose, same solvent. \\
\hline 4b & $1 \cdot 05$ & 74 & Column chromatography, silica, $\mathrm{CHCl}_{3}$ \\
\hline $5 \mathbf{b}$ & $3 \cdot 0$ & 42 & Column chromatography, silica, $\mathrm{CHCl}_{3}$. \\
\hline $5 c$ & 30 & 17 & Column chromatography, silica, $\mathrm{CHICl}_{3}$. \\
\hline $\mathbf{6 b}$ & $3 \cdot 0$ & 31 & Column chromatography, silica, $\mathrm{CHCl}_{3}$. \\
\hline $7 \mathbf{b}$ & $2 \cdot 1$ & 32 & Preparative plate, silica, ether. \\
\hline 8 & & 36 & Preparative plate, silica, ether. \\
\hline
\end{tabular}

purification by chromatography. In the reaction with $\mathbf{5 a}$, the ethyl ester $\mathbf{5 c}$ was produced in addition to the amide $\mathbf{5 b}$.

The amides $\mathbf{6}$ and $\mathbf{8}$ were carbonates, as shown by IR and NMR spectroscopy. Compound $\mathbf{8}$ was obtained simultaneously with the amide $7 \mathbf{b}$. All the amides $(\mathbf{1 - 6}, \mathbf{8})$ and the ester $(\mathbf{5 c})$ gave acceptable analytical data and showed the expected carbonyl absorption in the IR (Table 2a).

It was also possiblc to obtain melting points and ${ }^{1} \mathrm{H}-\mathrm{NMR}$ data (Table $2 \mathrm{~b}$ ) for the products 4-8.

To examine an amine model more closcly resembling the structure of wool, the amino acid lysine was used. Lysine was first reacted with the $\mathrm{Cu}(\mathrm{II})$ ion, which complexed the $\alpha$-amino and carboxylic groups. ${ }^{5}$ The $\varepsilon$-amino group of the protected amino-acid was then allowed to react with the activated dyes ${ }^{7}$ and finally the copper was removed ${ }^{9}$ by using ethylenediamine tetra-acetic acid (EDTA), thus giving the amides 9 and $\mathbf{1 0}$ (Scheme 2), which were characterised by IR and elemental analysis.

\section{A PRELIMINARY STUDY OF THE REACTIVE DYEING OF WOOL AND NYLON}

Having succeeded so far with the model compounds, it was decided to use this method of activation of carboxylic groups as a means of reactive dyeing wool and nylon-6.6. The carboxy dyes 4a-6a and 7 were treated with ethyl chloroformate as described and in their activated form were used to dye wool and nylon. 
TABLE 2

(a) Characterisation Data for $N$-Cyclohexylamide Dyes $1 \mathrm{~b}-7 \mathrm{~b}, 8$ and Ester $5 \mathrm{c}$

\begin{tabular}{|c|c|c|c|}
\hline \multirow[t]{2}{*}{ Compound } & \multicolumn{2}{|c|}{ Elemental analysis $(\%)$} & \multirow{2}{*}{$\begin{array}{c}\text { Infrared } \\
(C-O) \\
\text { absorption } \\
\left(v \mathrm{~cm}^{-1}\right)\end{array}$} \\
\hline & Theory & Found & \\
\hline 1b & $\begin{array}{l}\mathrm{C}(56 \cdot 32), \mathrm{H}(4.69), \mathrm{N}(11.42) \\
\mathrm{C}_{23} \mathrm{H}_{23} \mathrm{~N}_{4} \mathrm{O}_{5} \mathrm{SNa}\end{array}$ & $\mathrm{C}(55 \cdot 7), \mathrm{H}(5 \cdot 15), \mathrm{N}(11.05)$ & 1635 \\
\hline $2 \mathbf{b}$ & $\begin{array}{l}\mathrm{C}(41 \cdot 6), \mathrm{H}(4 \cdot 52), \mathrm{N}(8 \cdot 43) \\
\mathrm{C}_{23} \mathrm{H}_{23} \mathrm{ClN}_{4} \mathrm{O}_{8} \mathrm{~S}_{2} \mathrm{Na}_{2}, 2 \mathrm{H}_{2} \mathrm{O}\end{array}$ & $\mathrm{C}(41 \cdot 5), \mathrm{H}(4 \cdot 1), \mathrm{N}(8 \cdot 43)$ & 1635 \\
\hline 3b & $\begin{array}{l}\mathrm{C}(56 \cdot 68), \mathrm{H}(5 \cdot 37), \mathrm{N}(6 \cdot 84) \\
\mathrm{C}_{29} \mathrm{H}_{28} \mathrm{~N}_{3} \mathrm{O}_{6} \mathrm{SNa}_{2}, 2 \cdot 5 \mathrm{H}_{2} \mathrm{O}\end{array}$ & $\mathrm{C}(56 \cdot 7), \mathrm{H}(5 \cdot 4), \mathrm{N}(6 \cdot 3)$ & 1640 \\
\hline $\mathbf{4 b}$ & $\begin{array}{l}\mathrm{C}(68 \cdot 48), \mathrm{H}(6 \cdot 2), \mathrm{N}(17 \cdot 36) \\
\mathrm{C}_{23} \mathrm{H}_{25} \mathrm{~N}_{5} \mathrm{O}_{2}\end{array}$ & $\mathrm{C}(67.8), \mathrm{I}(6.35), \mathrm{N}(16.45)$ & 1632 \\
\hline $5 \mathbf{b}$ & $\begin{array}{l}\mathrm{C}(72 \cdot 0), \mathrm{H}(7 \cdot 42), \mathrm{N}(16 \cdot 0) \\
\mathrm{C}_{21} \mathrm{H}_{26} \mathrm{~N}_{4} \mathrm{O}\end{array}$ & $\mathrm{C}(71.8), \mathrm{H}(7.55), \mathrm{N}(15.75)$ & 1630 \\
\hline $5 c$ & $\begin{array}{l}\mathrm{C}(68 \cdot 68), \mathrm{H}(6 \cdot 39), \mathrm{N}(14 \cdot 14) \\
\mathrm{C}_{17} \mathrm{H}_{19} \mathrm{~N}_{3} \mathrm{O}_{2}\end{array}$ & $\mathrm{C}(67.55), \mathrm{H}(6 \cdot 30), \mathrm{N}(13.75)$ & 1723 \\
\hline $\mathbf{6 b}$ & $\begin{array}{l}\mathrm{C}(70 \cdot 11), \mathrm{H}(6 \cdot 07), \mathrm{N}(9 \cdot 44) \\
\mathrm{C}_{26} \mathrm{II}_{27} \mathrm{~N}_{3} \mathrm{O}_{4}\end{array}$ & $\mathrm{C}(69 \cdot 35), \mathrm{H}(6 \cdot 1.5), N(9 \cdot 3)$ & $\begin{array}{l}1755 \\
1630\end{array}$ \\
\hline $7 b$ & $\begin{array}{l}\mathrm{C}(70-12), \mathrm{H}(4-97), \mathrm{N}(6.06) \\
\mathrm{C}_{27} \mathrm{H}_{23} \mathrm{~N}_{2} \mathrm{O}_{4} \mathrm{Na}\end{array}$ & $\mathrm{C}(69 \cdot 35), \mathrm{I}(5 \cdot 40), \mathrm{N}(5 \cdot 80)$ & 1620 \\
\hline 8 & $\begin{array}{l}\mathrm{C}(70 \cdot 30), \mathrm{H}(5 \cdot 47), \mathrm{N}(5 \cdot 47) \\
\mathrm{C}_{30} \mathrm{H}_{28} \mathrm{~N}_{2} \mathrm{O}_{6}\end{array}$ & $\mathrm{C}(69.65), \mathrm{H}(5.60), \mathrm{N}(5.55)$ & $\begin{array}{l}1625 \\
1670 \\
1755\end{array}$ \\
\hline
\end{tabular}

(b) NMR Data for Dyes $4 b-7 b, 5 c$ and 8

\begin{tabular}{|c|c|}
\hline Compound & ${ }^{1} H-N M R$ \\
\hline $\mathbf{4 b}$ & $\begin{array}{l}\delta\left(60 \mathrm{MHz}, \mathrm{CdCl}_{3}\right) 0 \cdot 5-2(11 \mathrm{H}, \mathrm{m}, \text { cyclohexylamine }), 2 \cdot 3\left(3 \mathrm{H}, \mathrm{s}, \mathrm{CH}_{3}\right), \\
6 \cdot 4-8 \cdot 15(10 \mathrm{H}, \mathrm{m}, \mathrm{Ar}-\mathrm{H})\end{array}$ \\
\hline $5 \mathbf{b}$ & $\begin{array}{l}\delta\left(60 \mathrm{MHz}, \mathrm{CDCl}_{3}\right) 0 \cdot 75-2 \cdot 20(11 \mathrm{H}, \mathrm{m}, \text { cyclohexylamine }), 3 \cdot 0(6 \mathrm{H}, \mathrm{s} \\
\left.\mathrm{NMe}_{2}\right), 6-1(1 \mathrm{II}, \text { broad s, } \mathrm{NH}), 6 \cdot 75(2 \mathrm{H}, \mathrm{d}, J=8 \mathrm{~Hz}, 2 \times \mathrm{H} \text { ortho to } \\
\left.\mathrm{NMc}_{2}\right), 7 \cdot 15-8 \cdot 14\left(6 \mathrm{H}, \mathrm{m}, 2,4,5,6-\mathrm{H} \text { and } 2 \times \mathrm{H} \text { meta to } \mathrm{NMe}_{2}\right)\end{array}$ \\
\hline $5 \mathbf{c}$ & $\begin{array}{l}\delta\left(60 \mathrm{MHz}, \mathrm{CDCl}_{3}\right) 1.35\left(3 \mathrm{H}, \mathrm{t}, J=7 \mathrm{~Hz}, \mathrm{OCH}_{2} \mathrm{CH}_{3}\right) 3.02\left(6 \mathrm{H}, \mathrm{s}, \mathrm{NMe}_{2}\right), \\
4.35\left(2 \mathrm{H}, \mathrm{q}, J=7 \mathrm{~Hz}, \mathrm{OCH}_{2} \mathrm{CH}_{3}\right), 6.67(2 \mathrm{H}, \mathrm{d}, J=8 \mathrm{~Hz}, 2 \times \mathrm{H} \text { ortho to } \\
\left.\mathrm{NMe}_{2}\right), 7 \cdot 15-8.15\left(6 \mathrm{H}, \mathrm{m}, 4,5,6-\mathrm{H} \text { and } 2 \times \mathrm{H} \text { meta to } \mathrm{NMe}_{2}\right), 8.43(1 \mathrm{H}, \mathrm{t} \\
J=1.5 \mathrm{~Hz}, 2-\mathrm{H})\end{array}$ \\
\hline 6h & $\begin{array}{l}\delta\left(60 \mathrm{MHz}, \mathrm{d}_{6}-\mathrm{DMF}\right) 0 \cdot 90-2 \cdot 20(11 \mathrm{H}, \mathrm{m}, \text { cyclohexylamine }), 1 \cdot 38(3 \mathrm{H}, \mathrm{t} \\
\left.J=7 \mathrm{~Hz}, \mathrm{OCH}_{2} \mathrm{CH}_{3}\right), 4 \cdot 33\left(2 \mathrm{H}, \mathrm{q}, J=7 \mathrm{~Hz}, \mathrm{OCH}_{2} \mathrm{CH}_{3}\right), 6 \cdot 20-7 \cdot 10(1 \mathrm{H}, \\
\text { broad s, NH), } 7 \cdot 45-8.90(10 \mathrm{H}, \mathrm{m}, \mathrm{Ar}-\mathrm{H})\end{array}$ \\
\hline $7 \mathbf{b}$ & $\begin{array}{l}\delta\left(60 \mathrm{MHz}, \mathrm{CDCl}_{3}\right) 1 \cdot 0-2 \cdot 20(11 \mathrm{H}, \mathrm{m} \text {, cyclohexylamine }), 5 \cdot 8-6 \cdot 1(1 \mathrm{H} \text {, } \\
\text { broad s, NH), 6.9-8.4 }(11 \mathrm{H}, \mathrm{m}, \mathrm{NH} \text { and } \mathrm{Ar}-\mathrm{H})\end{array}$ \\
\hline 8 & $\delta\left(60 \mathrm{MHz}, \mathrm{CDCl}_{3}\right) 1 \cdot 0-2 \cdot 2\left(14 \mathrm{H}, \mathrm{m}\right.$, cyclohexylamine and $\left.\mathrm{OCH}_{2} \underline{\mathrm{CH}_{3}}\right)$ \\
\hline & $\begin{array}{l}3 \cdot 8-4 \cdot 2(1 \mathrm{H}, \text { broad } \mathrm{s}, \mathrm{NH}), 4 \cdot 2-4 \cdot 7\left(2 \mathrm{H}, \mathrm{q}, J=7 \mathrm{~Hz}, \mathrm{OCH}_{2} \mathrm{CH}_{3}\right), 7 \cdot 1-8 \cdot 5 \\
(11 \mathrm{H}, \mathrm{m}, \mathrm{NH} \text { and } \mathrm{Ar}-\mathrm{H})\end{array}$ \\
\hline
\end{tabular}




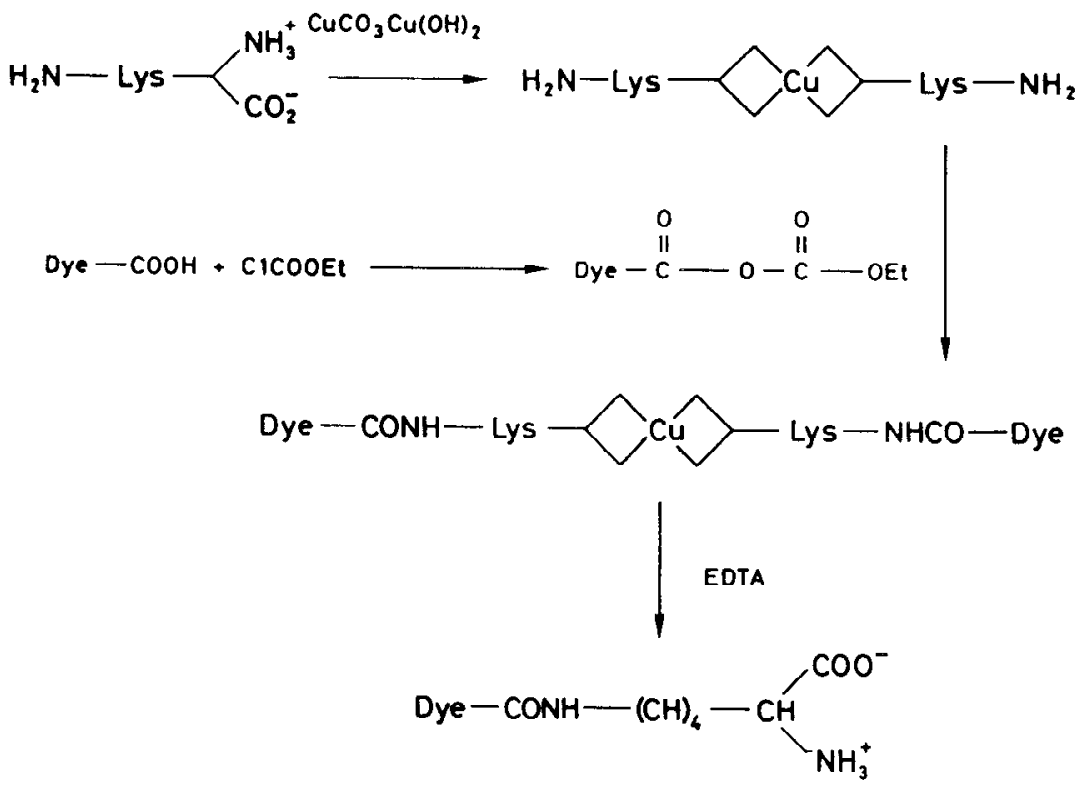

Scheme 2

The dyes were activated in DMF as described, for $20 \mathrm{~min}$, and the tricthylamine hydrochloride was then filtered off. The DMF solution was added to water $(150 \mathrm{ml})$ with stirring and, after adding the fibre, the mixture was boiled for $30 \mathrm{~min}$. The fibre was removed, washed, boiled for $15 \mathrm{~min}$ with soap and water and then submitted to the ISO $105 \mathrm{CO} 3$ test. The results of the test for the four dyes are shown in Table 3, and it can be seen that fastness properties are far superior to those expected for conventional acid dyeing with the carboxy dyes, indicating significant fixation of the chromophore to the fibre.

TABLE 3

Wash Fastness of Reactivc Fibres Dyed with Carboxy Dyes 4a-7a

\begin{tabular}{cccc}
\hline Carboxy dye & Colour & \multicolumn{2}{c}{ Change in shade } \\
& & Wool & Nylon-6.6 \\
\cline { 3 - 4 } & & With acrivation & With activation \\
\hline $\mathbf{4 a}$ & Yellow & 4 & $4-5$ \\
$\mathbf{5 a}$ & Yellow & 4 & $4-5$ \\
$\mathbf{6 a}$ & Orange & 34 & $4-5$ \\
$\mathbf{7 a}$ & Blue & 3 & 4 \\
\hline
\end{tabular}




\section{EXPERIMENTAL}

\subsection{General procedure for the reaction of dyes with cyclohexylamine}

The dye was dissolved in dimethylformamide (DMF), the temperature was maintained at -5 to $-10^{\circ} \mathrm{C}$ (external cooling with ice in methanol), and triethylamine and then ethyl chloroformate in equimolar amounts were added. The cold mixture was stirred until most of the dye had reacted (monitored by TLC) (typically about $15 \mathrm{~min}$ ). (yclohexylamine was added and the mixture was stirred at room temperature overnight. Triethylamine hydrochloride was filtered off and the solution was evaporated to dryness under reduced pressure. The resulting mixture was then purified by column or preparative thin-layer chromatography on silica or cellulose.

\subsection{Procedure for the reaction with lysine}

\subsubsection{Preparation of lysine-copper complex}

To a solution of DL-lysine monohydrochloride $(1.8 \mathrm{~g}, 10 \mathrm{mmol})$ in water $(100 \mathrm{ml})$, cupric carbonate (basic, $3 \mathrm{~g}$ ) was added slowly. After boiling for $2 \mathrm{~h}$, the undissolved cupric carbonate was removed from the hot mixture by filtration and washed with hot water $(10 \mathrm{ml})$. The filtrate and washings were combined and treated with acetone until a precipitate formed. The liquor was allowed to stand for $3 \mathrm{~h}$, filtered, and the residue dried, giving the complex as a blue powder $(2 \cdot 1 \mathrm{~g}, 60 \%)$.

\subsubsection{Synthesis of the amide dye-lysine 9}

The dye $(0.5 \mathrm{~g}, 1.9 \mathrm{mmol})$ was dissolved in a mixture of dimethylformamide $(100 \mathrm{ml})$ and triethylamine $(0.77 \mathrm{ml}, 5.6 \mathrm{mmol})$, and to this was added ethyl chloroformate $(0.53 \mathrm{~g}, 4.9 \mathrm{mmol})$ maintaining a temperature of -5 to $-10^{\circ} \mathrm{C}$. After stirring for $20 \mathrm{~min}$, a solution of the lysine-copper complex $(0.33 \mathrm{~g}, 1.9 \mathrm{mmol})$ in water $(3 \mathrm{ml})$ was added. The mixture was stirred at room temperature overnight and the yellow product $(0.8 \mathrm{~g}, 52 \%)$ was filtered off and dried.

Removal of copper. The solid $\mathbf{9}(0.8 \mathrm{~g})$ was dissolved in $2 \mathrm{M}-\mathrm{HCl}(45 \mathrm{ml})$, and an aqueous solution of ethylenediamine tetra-acetic acid $(0.1 \mathrm{M}, 20 \mathrm{ml})$ was added. The mixturc was stirred for $1 \mathrm{~h}$ and an aqueous solution of $\mathrm{NaOH}$ $(2 \mathrm{M})$ was added. The resultant precipitate was filtered off, washed with water and ethanol, and dried. The product was dissolved in $2 \mathrm{M}-\mathrm{HCl}$ and reprecipitated with $2 \mathrm{M}-\mathrm{NaOH}$. It was filtered off, washed with water and ethanol and dried to give the amide 9 as a yellow solid $(0 \cdot 18 \mathrm{~g}, 25 \%$ ), m.p. $208-210^{\circ} \mathrm{C} ; v_{\max }\left(\mathrm{KBr}\right.$ disc) $3300,1638,1600 \mathrm{~cm}^{-1}$. Found: $\mathrm{C}, 60 \cdot 9 ; \mathrm{H}, 6 \cdot 7 ; \mathrm{N}$, 16.65. $\mathrm{C}_{21} \mathrm{H}_{27} \mathrm{~N}_{5} \mathrm{O}_{3} \cdot \mathrm{H}_{2} \mathrm{O}$ requires $\mathrm{C}, 60 \cdot 72 ; \mathrm{H}, 6.99 ; \mathrm{N}, 16.87 \%$. 
4.2.3 Synthesis of the amide dye-lysine $\mathbf{1 0}$

The dye $(0.6 \mathrm{~g}, 1.7 \mathrm{mmol})$ was dissolved in a mixture of DMF $(150 \mathrm{ml})$ and triethylamine $(0.28 \mathrm{ml}, 2.0 \mathrm{mmol})$ and to this was added ethyl chloroformate $(0.2 \mathrm{ml}, 2.0 \mathrm{mmol})$ while keeping the mixture at a temperature of $-5^{\circ} \mathrm{C}$. After stirring for $10 \mathrm{~min}$, a solution of the lysine-copper complex $(0.3 \mathrm{~g}$, $0.85 \mathrm{mmol})$ in cold water $(40 \mathrm{ml})$ was added. The mixture was stirred at room temperature overnight and the yellow solid was filtered off, washed with water and ethanol, and dried.

Removal of copper. The crude solid was dissolved in 0.1 M-EDTA $(50 \mathrm{ml})$ when a yellow product precipitated on cooling. This was filtered off and washed with water and ethanol and dried $(0.48 \mathrm{~g}, 62 \%)$. Part of the solid $(0.2 \mathrm{~g})$ was dissolved in DMF with a few drops of $6 \mathrm{M}-\mathrm{HCl}$. A $4 \mathrm{M}$ solution of $\mathrm{NaOH}$ was added until a precipitate formed. The yellow solid was filtered off, washed with water and ethanol and dried to give the amide 10 $(0.18 \mathrm{~g}$, scaled up yield $56 \%)$ m.p. $223-224^{\circ} \mathrm{C} ; v_{\max }(\mathrm{KBr}$ disc) 3400 , $1638 \mathrm{~cm}^{-1}$. Found: $\mathrm{C}, 59 \cdot 35 ; \mathrm{H}, 5 \cdot 7 ; \mathrm{N}, 18 \cdot 1 \% . \mathrm{C}_{23} \mathrm{H}_{26} \mathrm{~N}_{6} \mathrm{O}_{4} \cdot \mathrm{H}_{2} \mathrm{O}$ requires C, 58.97; II, 5.98; N, $17 \cdot 94 \%$.

\section{CONCLUSIONS}

It has been shown that carboxylic acid dyes can be reactivcly dyed on wool and nylon-6.6 using ethyl chloroformate as activating agent. Reaction of the dyes with the model amines cyclohexylamine and lysine'confirms that amide formation can occur via reaction with the free amino groups in the polymers, thus giving covalent linkage of the dye to the polymer. These bonds would be sufficiently strong to withstand the alkaline conditions used in the ISO 105 $\mathrm{CO} 3$ test, as indeed was the case.

Dyes with no sulphonic acid groups gave the best results, which suggests that the preferred carboxy dyes would not have too great an affinity for wool and nylon-6.6, which would imply that better levelness and less uneven dyeings could be achieved.

The low $\mathrm{pH}$ necessary for fixation is also an advantage since it means that there is less wool damage.

It is noteworthy that the dyes containing sulphonic groups (i.e. 1a-3a) did not fix on wool and nylon-6.6, even though they formed amides with cyclohexylamine. The possibility of extending this reactive system to the practical reactive dyeing of polyamidc fibres is the subject of further study, and will be reported in a future publication. 